\title{
Sistem Otomatis Pompa Air dan Sabun pada Wastafel Pencuci Tangan
}

\author{
Andrizal $^{1}$, Yultrisna ${ }^{2}$, Junaldi $^{3}$. Tuti Angraini ${ }^{4}$, Anton $^{5}$ \\ 12345 Jurusan Teknik Elektro, Politeknik Negeri Padang \\ Jurusan Teknik Elektro Politeknik Negeri Padang, Jl. Limau Manih Padang, 25164, Indonesia \\ *Corresponding Author, email:andrizal@pnp.ac.id
}

\begin{abstract}
Abstrak- Mencuci tangan merupakan kegiatan yang seharusnya rutin dilakukan setiap individu, apalagi saat terjadinya pandemik COVID-19 seperti saat ini. Banyak faktor yang membuat seseorang merasa malas dan tidak mau melakukan cuci tangan, salah satunya tidak ingin direpotkan oleh aktivitas saat melakukan cuci tangan seperti mengambil sabun, memutar keran dan lainnya. Penelitian ini bertujuan untuk membuat sebuah wastafel pencuci tangan dengan keran yang dapat beroperasi secara otomatis. Eksperimen telah dilakukan dalam bentuk pengujian respon sensor mendeteksi tangan pengguna berdasarkan jarak dan besar sudut pembacaan. Selanjutnya dilakukan pengujian kemampuan pengaturan delay waktu menggosok tangan sampai mengaktifkan pompa keran air untuk membilas. Berdasarkan hasil uji coba dan analisa yang dilakukan didapatkan respons sensor pada jarak minimal $4 \mathrm{~cm}$ dan jarak maksimal $140 \mathrm{~cm}$ dengan view atau area respon $110^{\circ}$ posisi horizontal dan $85^{\circ}$ pada posisi vertikal. Pompa air dan pompa sabun aktif selama 3 detik ketika tangan pengguna terdeteksi sensor mendekati ujung keran air. Pompa air keran kembali menyala setelah delay selama 23 detik, dan sistem mampu beroperasi secara otomatis $100 \%$. Sehingga waktu pengguna menggosok tangan minimal selama 20 detik sesuai standar protokol kesehatan dapat terpenuhi.
\end{abstract}

Kata kunci: Kontrol, keran_wastafel, otomatis.

Abstract - Hand washing is an activity that should be routinely done by every individual, especially during the COVID-19 pandemic. There are many factors that make someone feel lazy and do not want to wash their hands, one of the reason is not wanting to be bothered by hand washing activities such as taking soap, turning the faucet and others. Experiments have been carried out in the form of testing the response of the sensor to detect the user's hand based on the distance and the reading angle. Furthermore, the ability to set the delay time for rubbing hands was tested to activate the water tap pump for rinsing. Based on the results of trials and analyzes that have been done, the sensor response was obtained at a minimum distance of $4 \mathrm{~cm}$ and a maximum distance of $140 \mathrm{~cm}$ with a view or response area of $110^{\circ}$ horizontal positions and $85^{\circ}$ in the vertical position. The water pump and soap pump were active for 3 seconds when the user's hand was detected by the sensor approaching the end of the water tap. The water tap pump comes back on after being delayed for 23 seconds, and the system was able to operate $100 \%$ automatically. Thus the minimum time for users to rub their hands for 20 seconds according to health standard protocols could be met.

Keywords: Control, sink_faucet, automatic.

(c) 2020 Elektron Jurnal Ilmiah

\section{I.PENDAHULUAN}

Gerakan Masyarakat Hidup Sehat (GERMAS) merupakan suatu tindakan sistematis dan terencana yang dilakukan secara bersama-sama dengan kesadaran, kemauan dan kemampuan berperilaku sehat untuk meningkatkan kualitas hidup. Gerakan ini mengedepankan upaya promotif dan preventif, tanpa mengesampingkan upaya kuratif-rehabilitatif. Salah satu kegiatan GERMAS adalah kegiatan mencuci tangan [1]. Mencuci tangan adalah salah satu tindakan sanitasi dengan membersihkan tangan dan jari jemari dengan menggunakan air ataupun cairan lainnya oleh manusia dengan tujuan untuk menjadi bersih, sebagai bagian dari ritual keagamaan, ataupun tujuan-tujuan lainnya. Aktivitas cuci tangan merupakan tindakan yang sangat penting untuk dilakukan dalam menjaga kesehatan agar tidak terjangkit penyakit maupun penyebaran virus apalagi saat terjadinya pandemi global.
Tujuan mencuci tangan adalah untuk menghilangkan kotoran dan debu secara mekanis dari permukaan kulit dan mengurangi jumlah mikroorganisme sementara. Kebersihan tangan yang tak memenuhi syarat juga berkontrubusi menyebabkan penyakit terkait makanan, seperti infeksi bakteri salmonella E. Coli, dan saat ini adalah covid-19. Mencuci tangan dengan sabun akan membuat bakteri dan virus lepas dari tangan atau rusak. Cuci tangan merupakan salah satu cara untuk menghindari penyakit yang ditularkan melalui makanan. Fakta menyebutkan bahwa sekitar 80 persen dari seluruh kasus penyakit ditularkan melalui sentuhan tangan. Hal ini dikarenakan tangan merupakan anggota tubuh yang paling sering menyentuh mata, hidung dan mulut yang merupakan media masuknya virus kedalam tubuh manusia [2]. Tetapi permasalahan muncul ketika tidak semua orang mau dan terbiasa mencuci tangan, apalagi mencuci tangan sesuai dengan standar protokol kesehatan 
Ada beberapa alasan yang membuat rendahnya kepatuhan dan keinginan untuk mencuci tangan diantaranya kurangnya pemahaman, tidak ingin direpotkan dengan aktivitas cuci tangan, kesibukan, lupa, tidak peduli kesehatan dan lain-lain. Ada juga keluhan mengenai iritasi kulit karena sering cuci tangan dan pengaruh penggunaan sabun. Meskipun demikian, dari suatu telaah sistematik yang dilakukan WHO terhadap lebih dari 99 literatur yang meneliti efikasi cuci tangan guna menurunkan transmisi dan infeksi penyakit [3]. Dimasa pandemi COVID-19 yang merebak diseluruh dunia saat ini, sering mencuci tangan dengan sabun dan pada air yang mengalir merupakan salah satu cara yang efektif dan harus dilakukan oleh seluruh lapisan masyarakat untuk memutus rantai penyebaran.

Oleh sebab itu diperlukan tempat mencuci tangan atau wastafel dengan keran air dan keran sabun yang bekerja tanpa disentuh pengguna atau bekerja secara otomatis. Sistem yang dibuat ini memanfaatkan sensor infra red, sebagai pendetesi tangan dan diproses menggunakan mikrokontroller untuk mengaktifkan motor pompa air dan pompa sabun.

Beberapa penelitian yang terkait dan sudah dilakukan oleh beberapa peneliti sebelumnya:

A. Perancangan Prototipe Alat Cuci Tangan Otomatis Dengan Sensor Ultrasonik Hc-Sr04 Berbasis Pengendali Mikro Arduino Uno R3 Oleh Deni Prasetyo dan Jarwo pada penelitian ini didapatkan alat cuci tangan otomatis lebih efisien dibandingkan wastafel konvensional, karena alat cuci tangan otomatis mampu bekerja secara otomatis sehingga meminimalisir paparan bakteri ke tangan pengguna, selain itu alat cuci tangan otomatis juga mampu menyesuaikan diri dengan keinginan pengguna dimana alat akan menentukan mode cuci tangan berdasarkan tanggan pengguna yang masuk pertama kali. [4].

B. Rancang Bangun Sistem Wastafel Otomatis Berbasis Mikrokontroler Atmega8535 Dengan Menggunakan Sensor Fotodioda oleh Hafizur Rizki dan Wildian. Hasil penelitian dijelaskan sebagai berikut: Sistem wastafel aktif saat ada tangan memotong jalur sinar laser terhadap sensor dioda foto. Sistem wastafel terdiri dari 3 bagian yaitu otomatisasi keran air, tempat sabun dan pengering tangan. Solenoid valve digunakan untuk otomatisasi keran air dan tempat sabun. Pengering tangan menggunakan hair dryer yang telah dimodifikasi menjadi hand dryer. Solenoid valve pada keran air mampu bekerja untuk air yang bersumber langsung dari tandon air. Solenoid valve pada tempat sabun mampu bekerja untuk air yang tidak bersumber langsung dari tandon air. Jenis

pengguna terdeteksi, sistem akan mengaktifkan relay pompa keran dan pompa sabun secara bersamaan sabun yang digunakan minimal dengan komposisi antara air dan sabun dengan perbandingan 1:1[5].

C. Keran Air Otomatis Pada Tempat Berwudhu Menggunakan Sensor Ultrasonik Berbasis Arduino Uno oleh Romi S, Pamor G dan, Muhmmad I. Hasil penelitian yang didapatkan adalah keran air otomatis pada tempat berwudhu menggunakan sensor ultrasonik berbasis arduino uno merupakan sebuah perancangan keran otomatis di tempat wudhu yang digunakan untuk menghemat pemakaian air dengan mengontrol pemakaian air ketika sedang berwudhu. Alat ini dikontrol dengan menggunakan arduino uno sebagai pengendali utama, keran air otomatis ini menggunakan sensor ultrasonic sebagai pendeteksi keberadaan objek atau anggota tubuh manusia yang sedang berwudhu [6].

Perbedaan utama penelitian yang dilakukan ini dengan penelitian sebelumnya adalah pengguna tidak perlu direpot lagi saat mencuci tangan. Pengguna hanya meletakkan atau mendekatkan tangan pada ujung keran air, motor pompa air dan motor pompa sabun akan aktif menyemprotkan air bersamaan dengan sabun. Sistem ini juga dilengkapi dengan pengatur waktu agar proses menggosok tangan dengan sabun selama minimal 20 detik dapat terpenuhi sebelum dibilas dengan air bersih. Hal ini sesuai dengan anjuran pemerintah saat mencuci tangan dengan sabun dan air mengalir untuk mengurangi penyebaran COVID-19, yaitu selama minimal 20 detik.

Sistem ini dibuat dengan menggunakan sensor Sharp GP sebagai pendeteksi tangan pengguna. Sensor ini termasuk pada sensor jarak kategori optic dan dasarnya, sensor ini sama seperti sensor Infra Red (IR) konvensional dengan jangkauan deteksi sensor versi ini adalah sekitar $4 \mathrm{~cm}$ sampai $150 \mathrm{~cm}[7]$, [,8]. Hasil data sensor dihubungkan dengan mikrokontroller Arduino IDE (Integrated Development Environment) bersifat open source [9]. Output sistem, adalah relay untuk mengaktifkan motor pompa air dan motor pompa sabun. Sasaran yang diinginkan dari penelitian ini adalah mengajak masyarakat melakukan gerakan cuci sesuai standar atau protokol kesehatan, terutama bagi masyarakat yang merasa terbebani dan direpotkan dengan aktifitas cuci tangan.

\section{METODE}

Tahapan penelitian dimulai dengan membuat sistem elektronik yang terdiri dari modul yang diintegrasikan dengan sistem utama berupa mikrokontroller dan output sistem berupa relay untuk aktivasi motor pompa air dan pompa sabun. Selanjutnya dilakukan pembuatan mekanik sistem pencuci tangan dan digabungkan dengan sistem elektronik. Prinsip kerja sistem diperlihatkan pada algoritma gambar 1, ketika tangan

selama 3 detik. Selanjutnya timer akan menghitung mundur dari 20 detik, dan pengguna akan menggosok 
tangan dengan air yang sudah dicampur dengan sabun minimal 20 detik sesuai standar kesehatan untuk membunuh virus atau bakteri [10], [11]. Setelah timer 0, maka pompa keran air akan on selama 10 detik dan mengeluarkan air untuk membilas tangan. Mikrokontroler yang digunakan pada penelitian ini adalah Arduino UNO, Pin digital output mikrokontroller dihubungkan dengan relay. Ada 2 ouput digital dari mikrokontroller yang digunakan yaitu untuk mengaktifkan relay pompa air dan mengaktifkan relay pompa sabun.

Tahapan selanjutnya adalah uji coba sistem yang bertujuan untuk membuktikan hasil rancangan pada penelitian ini apakah sudah sesuai dengan tujuan yang diharapkan. Uji coba dilakukan dengan beberapa eksperimen diantaranya:

\section{A. Uji Respon Sensor}

Uji respon sensor bertujuan untuk mengetahui besar sudut pandang dan jarak yang mampu dideteksi sensor dengan objek dalam hal ini tangan pengguna. Pengujian dilakukan dengan mengukur jarak maksimal dan minimal antara sensor dan tangan pada posisi garis lurus. Pengujian besar sudut dalam satuan derajat untuk mengetahui luas sudut pandang dari sensor pada posisi horizontal dan posisi vertikal. Tujuan pengujian ini adalah untuk mendapatkan jarak dan besar sudut pandang sensor secara optimal untuk mendeteksi adanya tangan diujung atau dekat keran.

\section{II.B. Uji Aktivasi Pompa Air Dan Pompa Sabun Serta Uji Delay Waktu Menggosok Tangan.}

Pengujian ini bertujuan untuk membuktikan otomatisasi proses cuci tangan dalam hal ini pengguna tidak menyentuh keran air dan keran sabun atau tempat sabun. Selanjutnya pada pengujian ini juga untuk membuktikan bahwa proses menggosok tangan menggunakan sabun minimal selama 20 detik dapat terpenuhi. Pengujian ini dilakukan dengan cara pengujian langsung sebanyak 15 orang melakukan cuci tangan dan masing-masing sebanyak 3 kali. Dalam proses pengujian ini dihitung juga waktu setelah keran pompa air dan pompa sabun sampai pompa air kembali aktif untuk mengeluarkan air untuk pembilasan.

\section{HASIL DAN PEMBAHASAN}

Gambar 2 memperlihatkan diagram blok sistem yang dirancang. Data hasil deteksi sensor diproses menggunakan mikrokontroller dalam hal ini Arduino UNO. Output sistem adalah relay yang dihubungkan dengan pompa keran air dan pompa sabun. Untuk pompa keran air digunakan pompa dengan penggerak motor AC (Alternating Current), sementara untuk motor pompa sabun menggunakan motor DC (Direct Current).

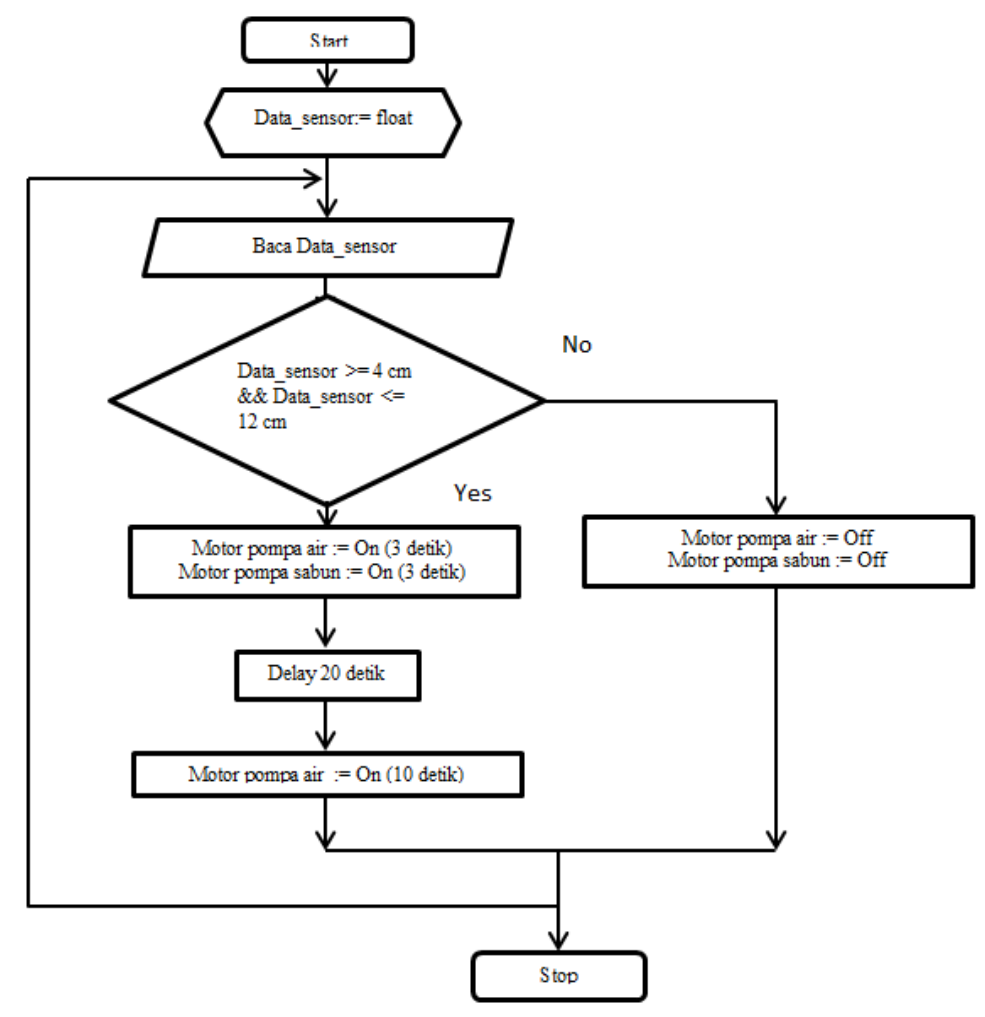

Gambar 1. Algoritma system 


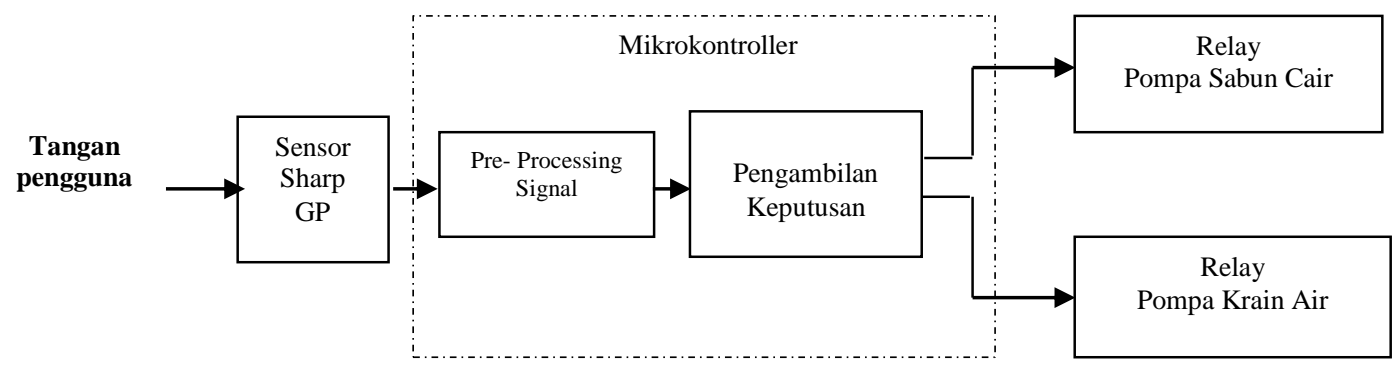

Gambar 2. Diagram blok system

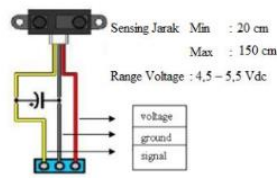

Gambar 3. Pin out pada sensor Sharp GP2Y0A02YK0F

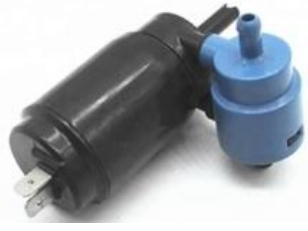

Gambar 4. Motor pompa sabun

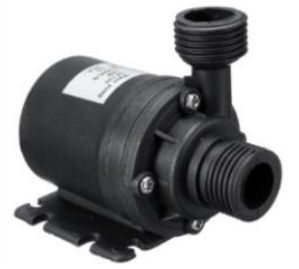

Gambar 5. Motor pompa air pembilas

Fungsi Sensor sharp GP adalah untuk membaca atau mendeteksi adanya tangan pengguna didekatkan pada ujung keran. Sensor ini menggunakan prinsip pantulan sinar infra merah. Gambar 3 memperlihatkan konfigurasi pin pada sensor sharp GP. Gambar 4 merupakan motor pompa dengan tegangan DC $12 \mathrm{Volt}$ yang digunakan untuk pompa sabun cair.

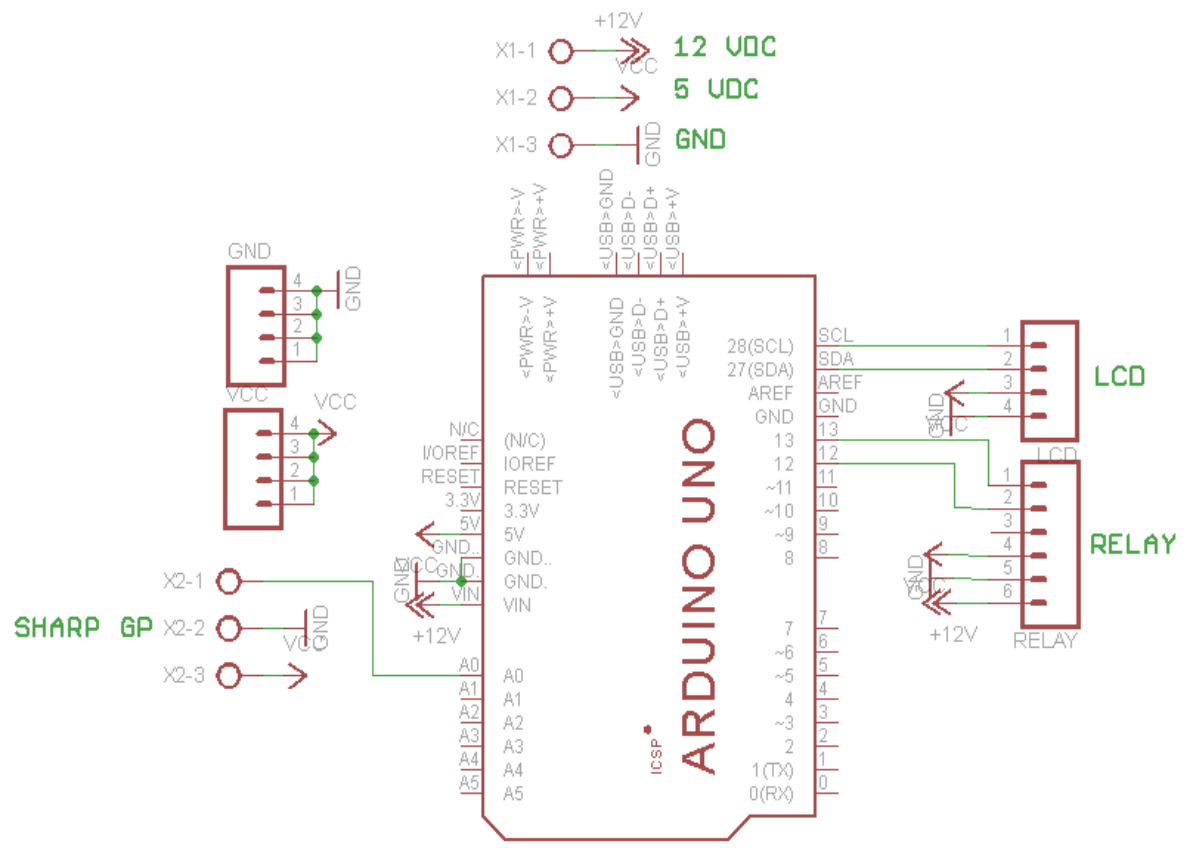

Gambar 6. Diagram rangkaaian sistem 
Sementara pada gambar 5 adalah motor pompa dengan tegangan DC $12 \mathrm{~V}$ ubtuk pompa air pembilas. Gambar 6 merupakan diagram skema rangkaian sistem secara keseluruhan mulai dari sensor sharp GP, pengkondisi sinyal, pre-processing dan pengambilan keputusan untuk menghasilkan output untuk relay pompa sabun dan relay untuk pompa air pembilas. Gambar 7 gambar sistem yang dirancang, alat ini dilengkapi dengan 2 sistem yaitu otomatis mekanik dan otomatis berbasis sensor elektronik. Pada tulisan ini dibatasi hanya membahas tentang otomatisasi berbasis sensor elektronik. Sensor diletakan dibagian bawah belakang keran, dimana keran ini berfungsi mengeluarkan air dan sabun,, serta air pembilas. Tabel 1 dan table 2 memperlihatkan hasil uji deteksi sensor terhadap tangan dengan jarak antara sensor dengan tangan berfariasi. Pengujian ini bertujuan untuk mengetahui kemampuan sensor untuk mendeteksi tangan yang didekatkan ke keran air. Jarak yang dijadikan referensi adalah garis lurus dari posisi sensor ke tangan pengguna. Dari table terlihat sensor mampu mendeteksi tanngan pada jarak minimal $4 \mathrm{~cm}$ dan maksimal pada jarak $140 \mathrm{~cm}$. Sementara view (luas sudut pandang dalam derajat ) dari sensor adalah maksimal $110^{\circ}$ pada sumbu horizontal dan $85^{\circ}$ pada sumbu vertikal. Jadi jarak yang dijadikan reverensi untuk mendeteksi tangan adalah minimal $4 \mathrm{~cm}$ dan maksimal $20 \mathrm{~cm}$.

Disamping itu tabel 1 juga merupakan hasil pengujian besar sudut deteksi dalam artian sudut pembacaan sensor atau view terhadap sumbu horizontal dan sumbu vertikal.

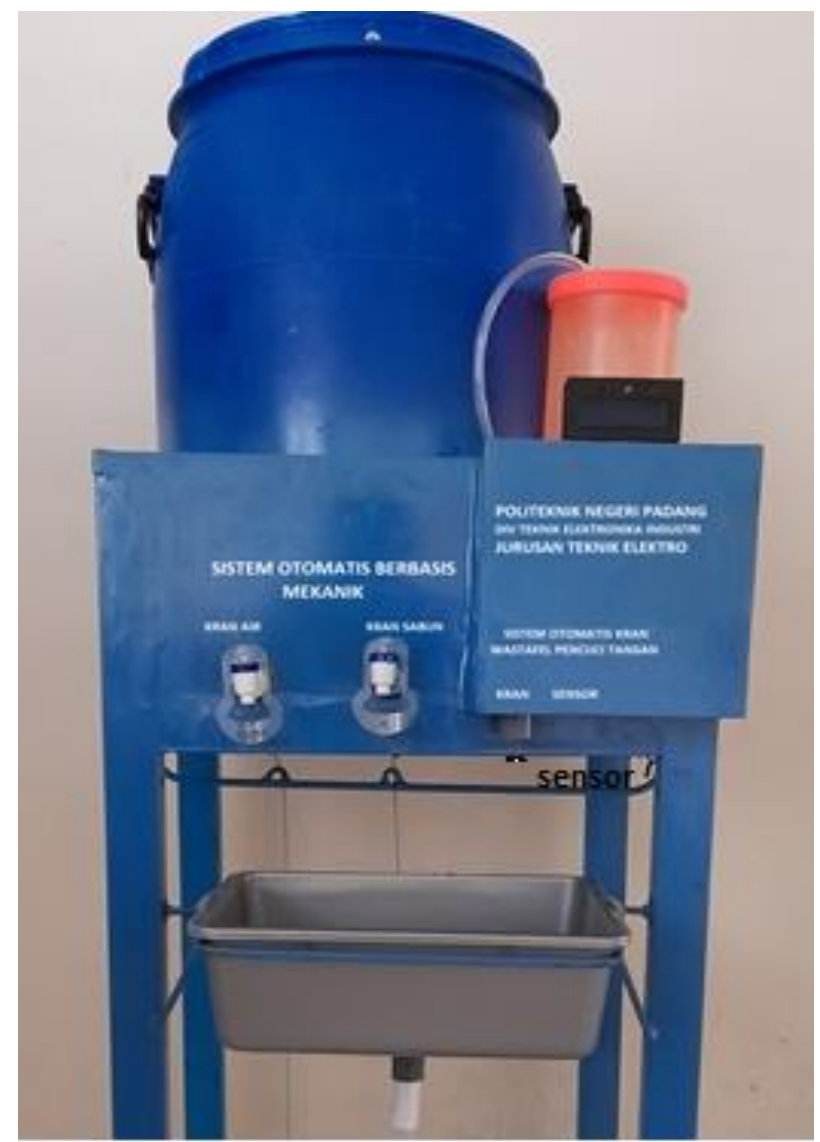

Gambar 7. Bentuk sistem secara keseluruhan

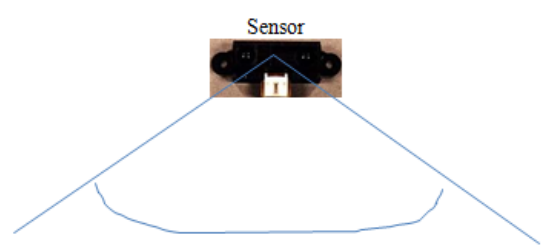

Gambar 8. View sumbu horizontal

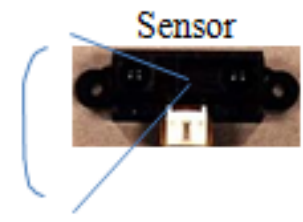

Gambar 9. View sumbu vertikal

Gambar 8 dan 9 menjelaskan posisi sudut pandang untuk kedua posisi dari sensor. Posisi 
vertikal memiliki sudut deteksi lebih besar dibandingkan pada posisi horizontal. Sehingga ketika tangan diarahkan ke posisi sensor, tidak selalu tangan harus berada pada posisi garis lurus. Dengan kemampuan ini menjadikan sensor ini lebih sensitif dan mampu membaca data tangan dari berbagai sisi.

Tabel 1. Hasil Uji View atau kemampuan deteksi sensor sharp GP berdasarkan lebar sudut pandang pada sumbu horizontal dan vertikal

\begin{tabular}{ccccl}
\hline No & $\begin{array}{c}\text { Jarak } \\
(\mathrm{cm})\end{array}$ & $\begin{array}{c}\text { Besar Sudut }\left(^{9}\right) \\
\text { Sumbu Horizontal }\end{array}$ & $\begin{array}{c}\text { Besar Sudut }\left(^{0}\right) \\
\text { Sumbu Vertikal }\end{array}$ & Keterangan \\
\hline 1 & 4 & 100 & 70 & Tangan Terdeteksi \\
2 & 10 & 105 & 80 & Tangan Terdeteksi \\
3 & 15 & 110 & 80 & Tangan Terdeteksi \\
4 & 20 & 110 & 80 & Tangan Terdeteksi \\
5 & 30 & 110 & 80 & Tangan Terdeteksi \\
6 & 40 & 110 & 80 & Tangan Terdeteksi \\
7 & 50 & 110 & 85 & Tangan Terdeteksi \\
8 & 60 & 110 & 85 & Tangan Terdeteksi \\
9 & 80 & 110 & 85 & Tangan Terdeteksi \\
10 & 100 & 110 & 85 & Tangan Terdeteksi \\
11 & 120 & 110 & 85 & Tangan Terdeteksi \\
12 & 140 & 110 & 85 & Tangan Terdeteksi \\
13 & 150 & 120 & 100 & Tangan Tidak Terdeteksi \\
14 & 160 & 120 & 100 & Tangan Tidak Terdeteksi \\
15 & 170 & 120 & 100 & Tangan Tidak Terdeteksi \\
16 & 180 & 120 & 100 & Tangan Tidak Terdeteksi \\
17 & 190 & 120 & 100 & Tangan Tidak Terdeteksi \\
18 & 200 & 120 & 100 & Tangan Tidak Terdeteksi \\
19 & 210 & 120 & 100 & Tangan Tidak Terdeteksi \\
20 & 220 & 120 & & Tangan Tidak Terdeteksi \\
\hline & & & & \\
\hline
\end{tabular}

Tabe 2. Hasil uji respons sensor sharp GP terhadap jarak objek secara garis lurus

\begin{tabular}{ccc}
\hline No & Jarak $(\mathrm{cm})$ & Hasil Deteksi Objek \\
\hline 1 & 3 & Tidak Terdeteksi \\
2 & 4 & Terdeteksi \\
3 & 5 & Terdeteksi \\
4 & 8 & Terdeteksi \\
5 & 10 & Terdeteksi \\
6 & 20 & Terdeteksi \\
7 & 30 & Terdeteksi \\
8 & 40 & Terdeteksi \\
9 & 100 & Terdeteksi \\
10 & 120 & Terdeteksi \\
11 & 140 & Tidak Terdeteksi \\
12 & 150 & Tidak Terdeteksi \\
\hline & &
\end{tabular}

Eksperimen selanjutnya adalah uji aktivasi motor pompa air dan motor pompa sabun. Ketika tangan terdeteksi, maka pompa air dan pompa sabun aktif bersamaan selama 3 detik. Proses uji ini ditampikan pada table 3. Referensi jarak yang digunakan adalah minimal $4 \mathrm{~cm}$ dan maksimal $12 \mathrm{~cm}$. Ketika jarak tangan dan sensor terpenuhi $4 \mathrm{~cm}$ sampai $12 \mathrm{~cm}$, maka sistem pompa air dan sabun aktif secara bersamaan dalam rentang waktu 3 detik. Campuran air dan sabun ini digunakan untuk menggosok tangan.

Jadi sistem yang dibuat ini mampu bekerja secara otomatis sehingga pengguna cukup mendekatkan tangan ke bagian ujung keran, selanjutnya pompa air secara bersamaan dengan pompa sabun mengeluarkan air dan sabun. Pengguna harus menggosok tangan dengan sabun selama minimal 20 detik. Setelah menggosok tangan dengan sabun selama 20 detik, keran air pembilas on dan mengeluarkan air selama 10 detik untuk membilas tangan pengguna. Hal ini sesuai dengan anjuran pemerintah tentang protokol kesehatan khususnya mencuci tangan dangan sabun dan air mengalir sebagai antisipasi penyebaran saat pandemi covid-19. 
Hasil uji selanjutnya ditampilkan pada table 4, yaitu berpa uji aktivasi pompa air dan sabun untuk mengeluarkan air dan sabun secara bersamaan secara otomatis, delay untuk menggosokan tangan dan aktivasi motor pompa air pembilas. Data hasil pengujian table 4 memperlihatkan pengujian sistem saat pengguna mulai mendekatkan tangan ke keran air, pengguna menggosok tangan dengan sabun dan membilas dengan air.

Tabel 3. Hasil uji aktivasi motor pompa air dan motor pompa sabun berdasarkan jarak tangan pengguna

\begin{tabular}{|c|c|c|c|c|}
\hline \multirow{2}{*}{ No } & \multirow{2}{*}{ Jarak tangan } & \multicolumn{2}{|c|}{ Aktivasi Pompa } & \multirow{2}{*}{ Keterangan } \\
\hline & & Air & Sabun & \\
\hline 1 & 4 & On & On & \multirow{5}{*}{$\begin{array}{c}\text { Waktu } \text { On motor } \\
\text { pompa selama } 3 \\
\text { detik }\end{array}$} \\
\hline 2 & 5 & On & On & \\
\hline 3 & 8 & On & On & \\
\hline 4 & 10 & On & On & \\
\hline 5 & 12 & On & On & \\
\hline 6 & 14 & Off & Off & \multirow{10}{*}{ Motor pompa $O f f$} \\
\hline 7 & 16 & Off & Off & \\
\hline 8 & 18 & Off & Off & \\
\hline 9 & 20 & Off & Off & \\
\hline 10 & 22 & Off & Off & \\
\hline 11 & 24 & Off & Off & \\
\hline 12 & 26 & Off & Off & \\
\hline 13 & 28 & Off & Off & \\
\hline 14 & 30 & Off & Off & \\
\hline 15 & 32 & Off & Off & \\
\hline
\end{tabular}

Tabel 4. Hasil uji aktivasi motor pompa keran air dan motor pompa sabun secara otomatis saat mencuci tangan

\begin{tabular}{|c|c|c|c|c|c|}
\hline \multirow{2}{*}{ No } & \multirow{2}{*}{$\begin{array}{c}\text { Jarak } \\
\text { tangan }\end{array}$} & \multicolumn{2}{|c|}{ Aktivasi Pompa } & \multirow{2}{*}{ Air pembilasan } & \multirow{2}{*}{ Keterangan } \\
\hline & & Air & Sabun & & \\
\hline 1 & 4 & On & On & On (setelah 23 detik) & \multirow{5}{*}{$\begin{array}{c}\text { Pompa sabun On } 3 \\
\text { detik, } \\
\text { Pompa air On } 3 \text { detik, } \\
\text { selanjutnya Off } 20 \\
\text { detik, dan kembali } \text { On } \\
10 \text { detik }\end{array}$} \\
\hline 2 & 5 & On & On & On (setelah 23 detik) & \\
\hline 3 & 8 & On & On & On (setelah 23 detik) & \\
\hline 4 & 10 & On & On & On (setelah 23 detik) & \\
\hline 5 & 12 & On & On & On (setelah 23 detik) & \\
\hline 6 & 14 & Off & Off & Off & \multirow{10}{*}{$\begin{array}{c}\text { Pompa air dan sabun } \\
\text { OFF }\end{array}$} \\
\hline 7 & 16 & Off & Off & Off & \\
\hline 8 & 18 & Off & Off & Off & \\
\hline 9 & 20 & Off & Off & Off & \\
\hline 10 & 22 & Off & Off & Off & \\
\hline 11 & 24 & Off & Off & Off & \\
\hline 12 & 26 & Off & Off & Off & \\
\hline 13 & 28 & Off & Off & Off & \\
\hline 14 & 30 & Off & Off & Off & \\
\hline 15 & 32 & Off & Off & Off & \\
\hline
\end{tabular}

Sistem bekerja secara sekensial, ketika tangan terdeteksi, maka keran air dan sabun beroperasi mengeluarkan air yang tercampur sabun selama 3 detik. Selanjutnya pengguna menggosok tangan sesuai 
dengan pewaktu yang diatur selama 20 detik. Terakhir pompa air aktif mengeluarkan air untuk membilas selama 10 detik. Dengan demikian cara ini mampu memaksa pengguna untuk mengikuti lama menggosok tangan dengan sabun sesuai dengan standar kesehatan dari Pemerintah dalam menekan penyebaran pandemi COVID-19.

\section{KESIMPULAN}

Dari hasil dan analisa data dapat disimpulkan bahwa penggunaan sensor sharp GP untuk mendeteksi tangan pengguna pada keran otomatis mampu mendeteksi tangan pengguna dari berbagai sisi dan jarak. Jarak baca sensor harus dibatasi antara $4 \mathrm{~cm}$ sampai $12 \mathrm{~cm}$ agar sistem tidak aktif walaupun ketika mendeteksi objek dengan jarak lebih dari $12 \mathrm{~cm}$. Dengan mengaktifkan keran air dan keran sabun secara bersamaan, maka secara otomatis air dan sabun dapat tercampur yang dapat digunakan oleh pengguna untuk menggosok tangan. Sistem mampu melakukan aktivasi keran sabun dan keran air secara otomatis $100 \%$ ketika jarak tangan dengan sensor $4 \mathrm{~cm}$ sampai $12 \mathrm{~cm}$. Pengaturan waktu delay untuk aktivasi pompa air pembilasan memberikan kesempatan kepada pengguna untuk menggosok tangan dengan sabun sebelum dibilas selama minimal 20 detik dapat dipenuhi.

\section{UCAPAN TERIMA KASIH \\ (ACKNOWLEDGEMENT)}

Terima kasih kepada P3M Politeknik Negeri Padang yang telah mendanai penelitian ini sebagai penelitian program studi DIV Teknik Elektronka Industri pada tahun 2020. Disamping itu juga ucapan terima kasih kepada rekan-rekan Tim Laboratorium Mikroprosesor dan Komputer Program Studi DIV Teknik Elekronika Industri Jurusan Teknik Elektro Politeknik Negeri Padang tempat penelitian ini dilaksanakan.

\section{REFERENSI}

[1] Eny Retna A, Prihastuti, Gerakan Masyarakat Hidup Sehat (Germas) Mencuci TanganMenggunakan Sabun Dan Air Mengalir Sebagai Upaya Untuk Menerapkan Perilaku Hidup Bersih Dan Sehat (Phbs) Sejak Dini, Jurnal Pengabdian Kepada Masyarakat, Vol 1, No 1, pp 45-52, April 2019.

[2] Nikmatul Ikhrom Eka Jayan, Kartini, Nurul Basirah,“ Formulasi Sediaan Sabun Cuci Tangan Ekstrak Jeruk Nipis (Citrus aurantifolia) dan Efektivitasnya sebagai Antiseptik" Media Pharmaceutica Indonesiana, Vol. 1 No. 4, Desember 2017.

[3] Arthur H.P. Mawuntu, Janri Tumbal, Michelle Pontoh, Yanti Mewo, Evaluation Of Effectiveness Of Washing Procedure On Operator Pungsi Lumbal In Part Neurology Rsup R.D. Kandou Manado, Jurnal Sinaps, Vol 1, No 1, pp 47-66, 2018.

[4] Deni Prasetyo, Jarwo, Perancangan Prototipe Alat Cuci Tangan Otomatis Dengan Sensor Ultrasonik Hc-Sr04 Berbasis Pengendali Mikro Arduino Uno R3, CYBER-TECHN. Vol 10 No 1, pp 18-29, 2015.

[5] Hafizur Rizki, Wildian, Rancang Bangun Sistem Wastafel Otomatis Berbasis Mikrokontroler Atmega8535 Dengan Menggunakan Sensor Fotodioda, Jurnal Fisika Unand, Vol. 4, No. 2, pp 107-112, April 2015.
[6] Romi S, Pamor G, Muhmmad I, Keran Air Otomatis Pada Tempat Berwudhu Menggunakan Sensor Ultrasonik Berbasis Arduino Uno, Sigma Teknika, Vol.2, No.2, pp 192-201, November 2019.

[7] Susilo Praptomo, Bambang Suprianto, Pengembangan Trainer Sensor Jarak Dan Warna Sebagai Media Pembelajaran Pada Mata Kuliah Komponen Elektronika Di Universitas Negeri Surabaya, Jurnal Pendidikan Teknik Elektro, Vol 4 No 1 pp 125-129, 2015.

[8] Hanifudin Sukri, Perancangan Mesin Cuci Tangan Otomatis dan Higienis Berbasis Kamera, REKAYASA, Journal of Science and Technology, Vol 12, No 2, pp163-167, 2019.

[9] Steven Jendri Sokop, Dringhuzen J. Mamahit, Sherwin R.U.A. Sompie, Trainer Periferal Antarmuka Berbasis Mikrokontroler Arduino Uno, E-Journal Teknik Elektro dan Komputer, Vol 3 No 3, pp 13-22, 2015.

[10] Intan Silviana Mustikawati, Perilaku Cuci Tangan Pakai Sabun Studi Kualitatif pada Ibu-Ibu di Kampung Nelayan Muara Angke Jakarta Utara; Studi Kualitatif , ARKESMAS, Vol 2, No 1, Juni 2017.

[11] Nurlina, Faisal Attamimi, Rosvina, Ilham Tomagola, Formulasi Sabun Cair Pencuci Tangan Yang Mengandung Ekstrak Daun Kemangi (Occimum basilicum L.), Jurnal As-Syifaa Vol 05 (02), Desember 2013. 